\title{
From warfare to welfare: veterans, military charities and the blurred spatiality of post- service welfare in the United Kingdom
}

Article

Accepted Version

Herman, A. and Yarwood, R. (2015) From warfare to welfare: veterans, military charities and the blurred spatiality of postservice welfare in the United Kingdom. Environment and Planning A, 47 (12). pp. 2628-2644. ISSN 1472-3409 doi: https://doi.org/10.1177/0308518X15614844 Available at https://centaur.reading.ac.uk/49103/

It is advisable to refer to the publisher's version if you intend to cite from the work. See Guidance on citing.

To link to this article DOI: http://dx.doi.org/10.1177/0308518X15614844

Publisher: Pion

All outputs in CentAUR are protected by Intellectual Property Rights law, including copyright law. Copyright and IPR is retained by the creators or other copyright holders. Terms and conditions for use of this material are defined in the End User Agreement.

www.reading.ac.uk/centaur 
Central Archive at the University of Reading

Reading's research outputs online 
From Warfare to Welfare: Veterans, Military Charities and the Blurred Spatiality of Post-Service Welfare in the United Kingdom

Agatha Herman [1] and Richard Yarwood (corresponding author) [2]

[1] Geography and Environmental Science

University of Reading

Reading

A.L.Herman@reading.ac.uk
[2] Geography, Earth and Environmental

Sciences

Plymouth University

Plymouth

R.Yarwood@plymouth.ac.uk

\section{Acknowledgements}

Many thanks to our reviewers, Rachel Woodward, Paul Simpson and Naomi Tyrell for their constructive feedback. 


\section{Abstract}

The military offers a form of welfare-for-work but when personnel leave they lose this safety net, a loss exacerbated by the rollback neoliberalism of the contemporary welfare state. Increasingly the third sector has stepped in to address veterans' welfare needs through operating within and across military/civilian and state/market/community spaces and cultures. In this paper we use both veterans' and military charities' experiences to analyse the complex politics that govern the liminal boundary zone of post-military welfare. Through exploring 'crossing' and 'bridging' we conceptualise military charities as 'boundary subjects', active yet dependent on the continuation of the civilian-military binary, and argue that the latter is better understood as a multidirectional, multiscalar and contextual continuum. Post-military welfare emerges as a competitive, confused and confusing assemblage that needs to be made more navigable in order to better support the 'heroic poor'.

\section{Keywords}

Military geography; welfare; veterans; transition; military charities; boundaries 


\section{Introduction}

The armed forces have long been significant in the provision of welfare, although its nature, extent and quality have varied over time and space. Cowen (2005: 655), drawing on the American experience, argues that military service offers 'a form of welfare for work' that rewarded service and sacrifice with access to public goods such as housing, health-care, pensions and recreation. These still provide an incentive to sign-up for the armed forces, especially amongst marginalised sections of society (Cowen and Siciliano, 2011). In contrast, military welfare in the UK formed a template for the provision of welfare to civilian society through the post-war formation of the welfare state and National Health Service (NHS), in part to compensate soldiers and citizens for their service to a national cause (Basham, 2013; Cowen, 2008a).

To date most academic research has focused on military welfare as a recruitment tool, particularly in the USA (Cowen and Siciliano, 2011; MacLeavy and Peoples, 2009), yet if enhanced welfare benefits are an incentive to join the armed forces, they are a necessity upon departure. Previous research has revealed that those leaving the forces, whether through choice, redundancy or medical discharge, are more likely to suffer from social or medical problems as a result of service life (Carlson et al., 2013; Higate, 2000; Johnsen et al., 2008; Mechanic, 2004; White et al., 2012). However, when people leave the military, their welfare ceases to be the concern of their unit and, instead, former military personnel rely on the civilian welfare state and/or an array of military charities and veterans' organisations, depending on the nature and length of their service. Very often the way that 'veterans' are defined determines who can access post-service welfare as well as the quantity and quality of that provision. In the USA more support is available to service personnel who have seen active service while Swedish employers look favourably on veterans. In Australia, a veteran is defined as someone been deployed actively overseas and, similarly, the Dutch treat a veteran as someone who has served in war or on United Nation operations (Dandecker et al., 2006). Differences not only exist between but also within countries (Basham, 2013; Skocpol, 1992; Ware, 2010), requiring ex-service personnel to negotiate a confusing and overlapping terrain of welfare 
provision upon leaving the armed forces. This has been given particular pertinence given the rollback of the civilian welfare state, troops being discharged from recent conflicts with mental or physical disabilities and large numbers of redundancies from the armed forces. ${ }^{1}$ There is a pressing need to understand better the ways in which post-military welfare is delivered to individuals but, to date, there has been little attempt by academics to piece this puzzle together or to examine how exService personnel are placed within the changing framework of welfare provision.

In this paper we begin to fill this gap by examining the complex and ambiguous terrain of ex-Service personnel's welfare in the UK by paying particular attention to the role of charities that specifically provide for serving personnel, veterans and their families (hereafter referred to as 'military charities'). Through exploring the contemporary landscape of military welfare in the UK, we introduce and develop the concept of 'boundary subjects', which recognises the simultaneous spanning of, but dependence on, a civilian-military binary by veterans' and military charities. This highlights the complex politics and dynamic power differentials as charities move in and out of different relationships with each other and the state; the increasing hybridisation of the third sector leads us to propose that the civilian-military binary is better understood as an adaptive continuum along which these relationships move. In this paper we explore and analyse the different ways in which the third sector maintains its position within the competitive and slippery landscape of military welfare in the UK through its relations with the state, ex-Service personnel and other organisations.

We recognise that the distinction between civilian and military spaces, practices and relations is blurred (Woodward, 2004) but, nonetheless, the discourse of a binary persists in the language, attitudes and practices of both military charities and ex-Service personnel (Herman and Yarwood, 2014). Important factors underlying the construction and persistence of this binary are the vested interests and entangled power relations that constitute this arena. The geographies of the civilianmilitary continuum, as experienced by ex-Service personnel, are real and everyday, lived through their domestic, work and leisure spaces and shaped by their social relations, mobilities and 
emotional geographies. However, here, we are focusing more abstractly on these perceived border zones in order to explore the social and power relations that shape welfare delivery. Boundaries have long played an integral part in social theorising (Riesch, 2010) and we recognise them as zones of interaction, which can lead to tension, negotiation, conflict and opportunity. Given third sector organisations' common position as 'gatekeepers' within military welfare in the UK it is therefore important to conceptualise the roles that they occupy, and the underlying politics of this, in order to better understand their relations with the users of their services. Recognising their role through the concept of 'boundary subjects' highlights the increasingly organisational nature of responding to welfare needs (Milligan and Fyfe, 2005), which offers a more complex and grounded understanding of how the nation deals with the moral obligations to its ex-Service personnel.

Our paper is divided into four main sections. We first introduce the third sector and its relations with the state, positioning this in relation to welfare in general and military welfare in particular. In the second section we position the military-civilian binary as a discursive construction and introduce the concept of the 'boundary subject' to analyse the complex inter-agency politics and relations involved in its continuing endurance, conceptualising this through third sector-state-market-community relationships. To explore these ideas, the empirical sections draw upon qualitative interviews with 25 ex-Service personnel and 11 military charity representatives ${ }^{\mathrm{ii}}$ conducted in 2012 in and around Plymouth, UK.iii This city has a large military presence and, although the number of people serving in the armed forces has declined, there are still around 20,000 veterans living in Plymouth (Devon County Council, 2014), making up nearly $10 \%$ of the adult population. ${ }^{\text {iv }}$ Given this concentration, a number of national and local Service charities are based in the city and its surroundings, which offer support for veterans. These include a Royal British Legion (RBL) drop-in office; the Naval Service Recovery Centre operated by Help for Heroes $(\mathrm{H} 4 \mathrm{H})$; a branch of the Soldiers, Sailors, Airmen and Families Association (SSAFA) as well as various regimental and service associations. Through exploring the experiences of both veterans and military charities we illuminate the ways in which military/civilian relations are understood and politicised by the individuals and organisations who 
move through and populate the military-civilian border-zone. We conclude by proposing that, while the rhetoric of a binary persists, a continuum offers a more accurate representation of the varying and dynamic relations and practices that constitute this border-zone between civilian and military, state and third sector. In our discussion, the contextual spaces of work, leisure and welfare fall into the background but remain critical to the experience of both organisations and individuals; furthermore, their mutually constitutive relations with the social (Valentine, 2001) ensure that the complex politics of this terrain translate into a blurred and porous spatiality, governed by the dynamism and contingency of the military-civilian continuum. Although our work is UK based, our exploration of post-rollback welfare makes our research relevant beyond the UK context in a range of neoliberal welfare settings and post-transitional landscapes.

\section{The State, the Third Sector and Welfare}

Simply defining the 'third sector' is intrinsically problematic as this wide, heterogeneous and dynamic grouping can seem highly disparate in practices, contexts and discourses (Alcock, 2012). Nonetheless, this assemblage of charities, social enterprises, community groups, nongovernmental organisations and co-operatives is generally broadly understood as 'not the state and not the market' (ibid: 221). However, in the UK and elsewhere, the third sector has assumed a growing role in public service delivery over the past 20 years (Alcock, 2012; Milbourne, 2009; Najam, 2000), which is breaking down the traditional distinctions between it, the state and the market. Relationships between the state and third sector are nothing new but the latter's 'hyperactive mainstreaming' in the UK from 1997 onwards (Kendall, 2009) combined with post-2008 austerity measures arguably exacerbates the tensions in these relationships as third sector organisations respond and adapt to budget-balancing cuts.

While relations with the state can be characterised by co-option and confrontation, they can equally reflect cooperation and complementarity, and the third sector is never simply a passive actant (Najam, 2000). In response to uncertain funding and a changeable political environment, the third 
sector has become an increasingly diverse set of organisations with hybridised structures (Smith, 2010) whose economic reliance on the state, donations, fees and earned income creates an increasingly blurred and complicated landscape between non- and for-profit motives (Phillips and Hebb, 2010). However, while the state has a symbiotic relationship with the third sector in the provision of social welfare and services (Mohan and Mohan, 2002; Yarwood, 2011) that has been characterised by a 'moving frontier' between the two (Finlayson, 1994; Kearns and Joseph, 1997; Mohan, 2003), we cannot simply relegate the latter to the position of a sub-contractor of state services. At different times and in different contexts, third sector organisations can operate both as insiders and outsiders; research by DeVerteuil and Wilson (2010) and Milligan and Fyfe (2005) highlights the dynamism of these relationships and the richness in terms of their on-the-ground materialisations. They also remind us that these are about responses to welfare needs and so, fundamentally, about care, whether this is understood as an organisational or a moral issue (Milligan and Fyfe, 2005). Equally, what emerges in these discussions is the unevenness in terms of spatial and social engagement by the third sector - a situation arguably governed by their unplanned and often needs-based emergence and differential engagement with the state and its resources. It is against this complex, uneven, dynamic and politicised background that we position the military charities that form the focus of our discussion.

\section{a. Armed forces Charities in the UK}

In this paper, we define military charities as those that provide some form of support for serving personnel, veterans and their families. Many of these can trace their routes to WWI and a desire by the public to care for the Service personnel and their families who had been wounded or bereaved in that conflict. Despite British Prime Minister Lloyd George's call for 'a country fit for heroes to live in' and the introduction of much social legislation, charities rather than the state were the backbone of welfare provision. Perhaps curiously, few military charities were established following WWII although many regimental associations were formed and thrived after this conflict; this may reflect 
the introduction of the NHS and National Insurance as part of the post-war reconstruction programme that introduced Fordist state-led welfare to the UK (Cowen, 2008b). Although military charities continued to play an important role, the duty of care shifted substantially towards the state.

However, from the 1980s onwards there has been a rise in the formation of new military charities. According to the Charity Commission (2012), 10-20 new military charities are registered each year in England and Wales with registrations peaking in 2010 when 44 new charities were registered. This coincided with a high point in British causalities in Afghanistan and widespread public support for their plight. Military charities also witnessed a 14\% increase in their income between 2008 and 2012 (Pozo and Walker, 2014), requiring many to register for the first time, according to the 2006 Charity Act, as their annual incomes topped $f 100,000^{\vee}$.

There are currently 2,050 charities associated with the armed forces in the UK (Ashcroft, 2014). These include cadets, heritage charities, regimental associations, grant-making benevolent trusts and a range of specialist service delivery charities. ${ }^{\mathrm{vi}}$ Of these $18 \%$ are welfare-related and have a growing role given current restructuring of the Services and the impacts of recent conflicts on Service leavers needs (Pozo and Walker, 2014). half of these are members of the Confederation of British Service and Ex-Service Organisations (COBSEO), an umbrella organisation that seeks to coordinate military charities, and accounts for over $90 \%$ of third sector income to armed forces charities (Ashcroft, 2014). Despite the number of military charities, most headquarters cluster in London and the South East suggesting that there are spatial gaps in the provision of care from the third sector (Pozo and Walker, 2014).

The growing significance of military charities since the 1980 s coincides with the well-documented state 'roll back' from welfare provision, placing greater reliance on the voluntary and private sectors to work in partnership to provide care (Peck and Tickell, 2002). Neoliberal strategies and welfare reforms mean that (ex)Service personnel are likely to receive less support from the state (Walker, 2013).. This benefits the state because the political risks of delivery responsibility are transferred 
while services are provided apolitically, cheaply and with a degree of consumer choice (Chaney and Wincott, 2014; Wolch, 1990). Furthermore, military charities help to enrol the public in the military and state's mission; many charities deploy discourses of 'heroism' or 'the warrior' to raise the profile of serving personnel, and position them as deserving of public sympathy and monetary support. At the same time, they are required by charity laws to be apolitical. By focusing on the lives of 'blokes'vii affected by war, charities allow the public to sympathise and support 'deserving' veterans while muting criticism of the wars that caused this need; however, the labelling of soldiers as 'heroes' implies a tacit support for recent campaigns. Mumford (2012) argues that high-profile charities raised societal awareness of military veterans by humanising their stories while, simultaneously, the-then coalition government developed policies based upon societal responsibility for veterans. The clearest expression of this was in the introduction of the Armed Force Covenant (2010) (AFC) that formalized the nation's moral obligation to its armed forces. Its two main principles were that Service personnel should not be disadvantaged in relation to other civilians and that special consideration should be given to the injured and the bereaved. There has also been a greater expectation that military charities will support, rather than be supported by, the MoD (ibid); money raised by $\mathrm{H} 4 \mathrm{H}$ has funded four state-owned Personnel Recovery Centres.

The State continues to support Service personnel in various ways, often prioritising veterans. Examples include the MoD Joint Service Housing Advice Office, 'help to buy' schemes and the Troops to Teachers programme; although their support for ex-Service personnel through Veterans UK appears more focused on advice and support around pensions and compensation, alongside a 24 hour helpline and referral service. The Ashcroft Review (2014) highlights that veterans are sometimes entitled to priority care from the NHS while some local authorities prioritise veterans when allocating social housing. ${ }^{\text {viii }}$ Nevertheless, accessing these services may be problematic since some veterans, particularly younger ones with a short service history, lack knowledge and experience of civilian institutions (Fossey, 2013) and may be unaware, for example, of how to register for a doctor or how to obtain housing support when they become civilians. There may also 
be a delay between leaving the Services and attempting to access help, either through lack of knowledge or recognition that problems exist. Help for ex-Service personnel is only provided 'up to a point' (Pozo and Walker, 2014) and the third sector has been of particular importance in addressing gaps during the recent recession and associated public sector cuts. However, the figurative minefield of welfare provision remains challenging:

'A Welsh veteran in need of a mobility scooter who served in the ranks of the Parachute Regiment would be eligible to receive support from a range of charities, including the Airborne Forces Security Fund, the Parachute Regimental Association, ABF The Soldiers' Charity, SSAFA Forces Help, the RBL and other relevant funds. In this instance, it is highly likely that he or she would be referred to a SSAFA Forces Help or RBL caseworker, who would then undertake a needs assessment on behalf of the veteran and co-ordinate the support of the relevant armed forces charities' (Charity Commission, 2012)

Additionally, a veteran would also be able to access welfare from other state and charity providers that serve the wider population and do not have a military remit. However, this highlights only the military side of the complex civilian-military assemblage that must be negotiated in order to access welfare. We now move on to introduce the concept of the 'boundary subject' as a way of understanding how the veterans and military charities in our study position themselves in the complex and over-lapping spaces of post-service welfare.

\section{Thinking through the welfare border zone: boundary subjects}

While we may dispute the binary nature common when thinking about civilian-military relations, spaces and practices, and recognise the constructed and contingent nature of this conceptualisation, it continues to affect, to varying extents, the lives and experiences of individuals and organisations (Herman and Yarwood, 2014). Understanding boundaries therefore continues to be important 'because they distinguish one domain or situation from another, ordering and simplifying the 
environment' (Ashforth, et al., 2000 in Watson-Manheim et al., 2012: 34) while the rhetorical and practical 'boundary work' of institutions and individuals creates and maintains a systematic, intelligible and governable domain and identity. However, this makes it easy for boundaries to appear as static signifiers of a container-like, reified space ignoring both the possibility of individuals identifying with multiple spaces and the dynamism of how individuals engage with boundaries, which leaves the latter as fluid, contextual and relational (Watson-Manheim et al., 2012).

To date, theorisation has drawn on Gieryn's (1983) 'boundary work' to explore Star and Griesemer's (1989) 'boundary objects', which enable intercommunication and consensus between different groups; and Guston's (1999) 'boundary organisations', similar to Ancona and Caldwell's (1992) 'boundary spanners', which manage the boundary, coordinating and facilitating action between domains. These literatures recognise that boundary work can be strategic; it can function to include or exclude others, make particular relations (in)visible or locate in relation to the boundary in certain, advantageous ways (Gieryn, 1999). This is because of the anticipated necessity for interfaces between communities to bridge perceived and actual differences (Karsten et al., 2001), which draws power to those operating 'on the ground' across these boundary zones, allowing them to be simultaneously sites of connection and separation (O'Leary et al., 2013). 'Whether we like it or not boundaries keep cropping up' (Edwards and Fowler, 2007: 121) but how do we recognise a boundary when it does? Following Watson-Manheim et al (2012) a boundary is only understood as such when it causes a discontinuity but we also argue that only when a disruption draws attention to the presence of difference is a boundary performed through both discourse and praxis. This disruption could be triggered by the realisation of a discrepancy between expectations and reality, by the experience of something novel or extraordinary or when attention is deliberately drawn to it. When we explore the role of the third sector it is clear that it occupies an increasingly problematic conceptual terrain between the state, society and market in terms of welfare provision. On the one hand these organisations usually emerged from the grassroots in response to particular needs and issues, and now 'provide relief to an ever-more disarmed welfare state' (Bode and Brandsen, 2014: 
1056) - a move given further impetus by the post-2008 global recession (Chaney and Wincott, 2014) - through locally grounded, participatory and innovative responses. On the other, in a funding environment governed by austerity measures, many are either increasingly dependent on government contracts, which act in tension with their position as independent actors (Alcock, 2012) and, arguably, situate them as state instruments (Defourny and Nyssens, 2010) or are becoming hybridised through a growing reliance on the market for income (Phillips and Hebb, 2010; Smith, 2010). This highlights the complicated and uneven balancing act which the third sector has to negotiate between financial sustainability, policy impact, service provision, organisational identity and responsibility to users, and positions these organisations as operating within, across and in tension with the border-zones between community, state and market (Brandsen and Pestoff, 2006). While boundary objects such as state-third sector compacts act as 'negotiated bridges' across these organisational and rhetorical boundaries, conceptualising the third sector organisations themselves as boundary objects, organisations or scanners is simplistic. Their active and strategic negotiation of this terrain refers to something more than simply an 'infrastructural phenomena' (Gal et al., 2004: 197), and we therefore propose the concept of the 'boundary subject' to address this theoretical gap.

A 'boundary subject' is an individual or organisation who has the capability to choose how they engage with community, market or state spaces while remaining subject to, and dependent on, the interactions enforced by the perceived boundaries between them. As both Najam (2000) and Alcock (2012) note, even when the state or market is dominant, the third sector still has agency within the relationship. Furthermore, these organisations arguably rely on the continuing perception of a boundary between the state, market and welfare users to make the case for their continuing utility through their unique capacity to work with and across these disparate groups (Bode and Brandsen, 2014). Their existence is therefore dependent on the continuation of these boundaries, which need to be maintained through rhetorical and practical boundary work in order to claim authority within the sector and to distinguish from other, competing organisations. This 
recognises that the 'boundary subject' is not only involved in regulating the trading zone that exists between, in the context of this paper, military and civilian cultures but is also engaged in enacting other spatial logics (Law and Singleton, 2005). It is extremely timely to consider how these ideas can be applied to understanding the provision of welfare across military and civilian domains, especially given recent initiatives aimed at supporting the well-being of ex- and serving Service personnel. In the UK, for example, the AFC aims to close the 'divide' between military and civilian worlds by enrolling state, private and voluntary organisations into local civilian-military partnerships to support troops and their families. In the following sections we empirically explore the ways in which military charities negotiate their positions as boundary subjects, using techniques to simultaneously bridge but also perpetuate the civilian-military divide for their service users, highlighting the vested interests and conflicting relations that shape this welfare terrain.

\section{Bridging the Divide: maintaining the Service Family}

For veterans, irrespective of their 'success' in transition or their time out of the Services, sentiments of loss were common and persistent, with individuals noting that 'leaving the Navy is a bit like losing your parents' (Veteran B, Interview, 26/06/12), and these feelings were often exacerbated by a corresponding loss of identity:

'You've been part of a special group of people. You may feel special, you look different, you act different, you have your own rules, you have your own language... and all of a sudden you're not' (Veteran A, Interview, 26/07/12)

However, military organisations can lessen the impact of this rupture through offering a degree of continuity spatially and relationally in terms of being part of a community, offering a support network of like-minded people as well as language and attitudes. Service charities, which are civilian organisations, deploy terms used by the military in order to maintain a close alignment with active units. The term 'esprit de corps' is widely used in the Services to describe the fighting spirit and 
traditions of a unit. Many veterans' charities also utilise the term, extending it beyond the space occupied by a unit or the time spent serving it in order to provide a sense of continuation. These terms are used most widely by regimental/unit associations, which aim to 'maintain contact between past and present members of regiment[s] and to foster esprit de corps amongst [their] members' (MoD 2014).

Significant numbers of organisations seek to bridge the discontinuity experienced upon moving from military to civilian culture by linking veterans with their former units as well as serving personnel. The Royal Marines Association (RMA), for example, aims to 'maintain and promote esprit de corps and comradeship amongst all Royal Marines and their families, past and present' (RMA 2014), and emphasizes this through the slogan 'once a marine, always a marine'; an active positioning by the charity as serving both current and former marines, and their families, emphasizes intergenerational solidarity. In addition, this connection to a unit positions the RMA in a clear niche within the 'market' of the Service-focused third sector, providing a strong raison d'etre for its existence because the charity receives support and membership from the Royal Marines, while the welfare of the unit is enhanced by the charity. Many charities use the explicit term 'family' to strengthen this bond, and emphasize their specific role; for example SAFFA uses the branding 'One Forces Family' to summarise its remit of support across all three Services.

Service charities operationalise this bridging role through creating various forms of liminal border zones for veterans and their families; these can be virtual, through websites or newsletters, or tangible such as social clubs. The RBL is one of the most well-known veterans' charities in the UK and, amongst other services, it coordinates branches and clubs in most UK cities, which provide a place where 'old boys go to drink beer and talk about old times' (Veteran B, Interview, 26/06/12). For some, any form of connection is beneficial and so numerous techniques are deployed '...to keep in touch with people on Linkedln or in the local pub, the British Legion, anything really' (Veteran C, Interview, 24/06/12). Military charities also serve as 'bridges' in terms of employment and volunteering, as one veteran commented: 
'We have always done quite a lot for the British Legion. So although that is still military, a lot of those people are now civilians and working in civvy street' (Veteran E, Interview, $07 / 12 / 12)$

The latter emphasizes the liminal nature of spaces provided by organisations such as the RBL. Most of the representatives of military charities that we spoke with were veterans, which highlights the blurred boundaries within the organisations themselves because while they are often staffed and populated by former military personnel, they are not formally part of the military:

'I left the Navy in 2001 and I literally left on a Friday and started here on a Monday... it's just like a continuation of our lives in the Navy. I answer the phone and I use my title when speaking to people who are just like me. So, it's just like an unpaid - I'm not paid by the Navy - extension of naval life.' (Organisation 4, Interview, 26/06/12)

Many of the specific unit associations organise annual reunions, which were important to some of our interviewees, although not all. Some wanted a clear separation between their military and civilian selves and lives, using the discontinuity between these spheres to move on with no regrets. For others, the opportunity to reminisce with former comrades enabled them to connect the different parts of their lives. For many, the military was more than just a career but also a lifestyle, a community and a way of relating to others; reunions allow people to reflect on experiences that their civilian friends are not able to relate to. While in general these reunions were just to enjoy the camaraderie of remembrance, for others these spaces were more challenging as they connected them back into military networks and spaces, which they were desperate to regain access to:

'...it was called the City Naval Lunch Club ... we're creating those spaces again so that you can meet your old chums and you can talk about old times... You got lots of people who are living and working in a civilian environment, desperately attempting to maintain this Service identity' (Organisation 4, Interview, 26/06/12) 
These social spaces and 'family' focused practices 'are associated with comradeship and membership and welfare, at the kind of stage-one low-level of welfare' (Organisation 2, Interview, 25/06/12), and reflect part of the jigsaw of provision by Service charities. So far we have focused on those practices and activities which 'bridge the binary' but the complex terrain of this border zone requires that service organisations enact multiple relations in terms of how they negotiate their position as 'boundary subjects' and the services this enables them to provide to end-users. For the latter, sometimes the military-civilian boundary is not experienced as bridged but as 'crossed', and we explore this experience through how organisations support the post-transition welfare needs of veterans.

\section{Crossing the Divide: Post-Transition Welfare}

For the majority, the military to civilian transition is experienced relatively seamlessly with few having significant or long-term problems in terms of employment, debt, housing, relationships or health (Ashcroft, 2014). However, for some, transition comes as a shock because it represents more than just the loss of their job:

'So, they lose their health. They lose their job. They lose their home. They lose their entire support network, all in a very short space of time' (Organisation 10, Interview, 16/08/12).

Cowen (2005) has argued that the military provides its personnel with access to forms of welfare that might otherwise be inaccessible to civilians; however this form of military welfare-for-work can create problems when individuals leave the welfare safety net that the Services provide:

'There has always been someone to fall back on. Worst comes to worst, your family falls apart, you know, you get divorced or other bits and pieces... In the past, you could just move back on board [i.e. out of family accommodation]... The day after they leave the service, if your marriage breaks down for whatever reason, no one's interested. The service isn't interested' (Organisation 7, Interview, 26/07/12) 
In preparation for leaving the Services, personnel are given guidance and training on returning to civilian life that includes advice on accommodation, health care, welfare and, significantly, the organisations that exist to help them if they encounter any problems. Certainly, as the quotes above suggest, the Services' responsibility for welfare ends when personnel leave with this responsibility being transferred to the state and the third sector. The state remains responsible for administering some forms of welfare and advice; Veterans UK, which is funded by the MoD, administers military pensions and compensation payments while veterans, like any member of the British public, can turn to local authorities for welfare in terms of housing and healthcare. Nonetheless, one interviewee argued that this was not enough for many personnel:

'The government has recently done this thing about reasonable preference towards veterans, but.... it's only a cursory nod and there's no legal compulsion behind it. So, local authorities have got other stuff to do ... they are never going to prioritise veterans to the extent we want, that's just the fact. The MoD focus heavily on transition and don't do very much around the long term veterans. They rely on the voluntary sector to do that' (Organisation 9, Interview, 20/08/12)

This increasing reliance on Service charities reflects the broader trends towards state-third sector partnerships in the delivery of welfare services, and many of our UK interviewees were keen to highlight their organisation's role in this welfare jigsaw. According to one interviewee, his charity was more accessible to veterans because of its 'boundary subject' status:

'They don't trust the MoD... because we're independent and this guy [the advisor] was a war vet, he's got no axe to grind. He's totally independent, good at third party advice ... he'll fix me to get some form of tiny war pension. He does that all the time, bloody expert...' (Organisation 8, Interview, 19/06/12)

Here, the liminal nature of the organisations, as evidenced by their staffing by veterans, enables them to provide a more empathetic and secure service to those who have crossed the boundary and require support. Milligan and Fyfe (2005) note that the general trend towards professionalization in 
many third sector organisations is impacting on their connections with volunteers from their original support base; yet military charities combine professionalization with the continuing engagement of ex-Services personnel perhaps because of their skills and continuing desire to be a part of, and supportive to, the wider Services 'family'.

Many military charities used their positioning as one within a patchwork of providers to signpost people towards the most appropriate - state or non-state - agencies indicating an increasing level of cooperation within the sector:

'...when someone comes to us with an issue, if we can't deal with it, we don't say, "We're terribly sorry. I can't see these people." We effectively share details and hand them over or signposting them to the appropriate charity or organisation that can help them' (Organisation 7, Interview, 26/07/12)

According to Pozo and Walker (2014) the military charity sector shows greater cooperation than other charitable sub-sectors. Despite this evidence of collaboration, organisations remained critical of each other's activities and, indeed, of the state agencies involved in welfare, particularly the Career Transition Partnership (CTP), the official route through which all ex-service personnel cross into civilian life:

'I don't personally have a very high opinion of what the CTP offers. It's done on a contract with an organisation called Right Management... They are paid per head if people pass through the Career Transition Workshop. They look after them in theory for two years before to two years after. The service is a very perfunctory two-and-a-half day course...It does give a veneer of looking at the outside world and generally speaking the gentlemen on the course are so excited by somebody suddenly taking an interest in them and they all say... "Gosh that was really good thank you." But if you look at the product in terms of the CVs they produce, the lack of any networking campaign or focus...And that's where we put a lot of our focus... we provide a contact list of ex-officers who are prepared to help... But the CTP doesn't do any of that' (Organisation 6, Interview, 13/07/12) 
We suggest that the particular critique of the CTP indicates both the strength and weakness of these organisations through their purported successes, which highlights their capacity to provide an alternative service, as well as their tenuous position as boundary subjects. They need to demonstrate the benefits of their particular, non-state positioning and strategy to providing an effective and sustainable boundary crossing for end-users. By utilising ex-Service personnel within their organisations, they are arguably better placed than the state agencies to connect with service users and so they are often recognised by ex-Service personnel as a first port of call. Many of the charities were very proactive in making service personnel aware of the support they offer both for those serving and ex-Service personnel:

'I write a letter and I give it to a service personnel organisation who then forwards the letters on to these guys, just making them aware of me. Most of them probably put it in their back pocket and think "I might need that one day" ... Everybody who leaves is aware of me, whether they choose to use me or choose to have contact with me is up to them' (Organisation 4, Interview, 26/06/12)

Organisations thus maintain their liminality in order to be able to speak, Janus-like, to both military and civilian worlds. This makes them critical boundary subjects in that they have the capacity to shape how individuals experience the boundary through acting as gatekeepers both to others in the state and non-state sectors, as well as guiding those entering the military or civilian spaces who require it. Their work with serving personnel and their families is also pertinent as organisations also negotiate the latter's' engagements with civilian cultures with one organisation noting that debt is currently the biggest social challenge for the serving personnel they support (Organisation 5, Interview, 30/06/12).

However, only a few of our ex-Service personnel interviewees had ever used military charities and self-identified as having been 'successful' in their transition with little need for support in crossing the boundary. ${ }^{i x}$ When they did use service charities, our respondents highlighted the selective way in which they negotiated their path through this complex terrain: 
I've not used any financial help. I had a bit of a problem with my flashbacks from Bosnia. I just needed them, you know, somebody to talk to... Financially, no. I feel a bit guilty asking because that's what guys from Afghanistan and Iraq need ... I could go and say, "Hi. Can you give me this? I want to go and do this for my...?" But I feel, there are more deserving people ... the thing is I don't need it...' (Veteran M, Interview, 14/09/12)

There was a general sense of reluctance to draw on the help that was available, with the suggestion that there were more deserving cases expressed by many former Service personnel, who largely felt that they had the capacity to negotiate their own paths with minimal assistance. Despite this, there was an appreciation that it was good to have the charities there 'just in case':

'It is nice to know that there are places outside of the normal Government bureaucracy, more someone like the British Legion who have seen so many cases that they can actually fight your corner. So, yeah, it's good and we know they are a very valuable service' (Veteran N, Interview, 13/12/2012)

How individuals engaged with the military charity sector positions the way they negotiate the military-civilian border zone as qualitatively different to the experiences of organisations. While they are boundary subjects in the sense that, largely, they have the capability to choose how they engage with military and civilian spaces, they are more transient and mobile and hence not dependent on the continuation of the binary in the same way that organisations are. While their identities often remain informed by their military experiences and so, in a sense, they inhabit this liminal space, it is more at a personal, micro-scale and they do not rely on the separation between military and civilian cultures which, at the institutional scale, makes organisations simultaneously (dis)empowered within this sector. Furthermore, while organisations' positions change as how they relate to each other, the state and communities changes this remains relatively bounded. In contrast, individuals appeared to have more fluid experiences of this border zone as an embodied element in their everyday lives, which they can cross and re-cross in both the short and long term through employment (re-enlisting or working for a military charity) or leisure (at a reunion, in the 
pub or while reminiscing with former comrades). We argue therefore that a continuum of civilianmilitary identities/spaces/practices is better suited to represent the dynamic, flexible, contingent and multi-directional relationships that both organisations and individuals have.

\section{The Camouflaged and Competitive Terrain of Military Welfare Provision}

Despite efforts at inter-agency referral and collaboration, the proliferation of the military third sector, combined with changing and competitive relations with the state, presents a confusing welfare landscape. The continuum introduced above helps to capture the fluctuating insider/outsider status as government tenders and community-based events come and go, changing the dynamics of organisations' relationships. If, as Cowen suggests, the military provides a form of welfare-for-work, it is delivered via an increasingly complex array of agencies; after Wolch (1990), we suggest that the third sector is providing former and serving personnel with welfare services that arguably should be the state's responsibility. Within the military charity sector there remains a plurality in terms of organisational model from more grassroots organisations to corporatist structures but a common thread in our interviewees' discussions was the potential for tension within the relationship with the state:

'I think sometimes, they [government] see us as amusements... They're there to save money and we're battling to fight for people's rights, and you know, sometimes, it's too conflicting. Yeah, I do think that sometimes they see us as a bit of an aggravation...' (Organisation 10, Interview, 16/08/12)

Many commentators position this tension as important in maintaining a healthy and responsive democracy (Phillips and Hebb, 2010) but at an organisational level the dichotomy presented by the need to balance partnership working with an independent stance can put a strain on, and reduce the coherence of, the mission (Smith, 2010). It is a contemporary reality that military charities form part of the mixed terrain of welfare provision that is now available to serving and former personnel. 
Arguably the proliferation of the third sector in military welfare from the 1980s has meant that these organisations form a patterned ground between military and civilian spaces that is blurred and overlapping. It is not only difficult for outside observers to distinguish the outlines of individual organisations but is also hard for those leaving the Services to position themselves in relation to this complicated and ambiguous terrain, despite the signposting by organisations mentioned above, because:

'I don't think that they necessarily recognise us for what we do as much as they could or should. And maybe that's because there are too many of us for them to deal with and for them to understand what we all do' (Organisation 10, Interview, 16/08/12)

While this diversity did offer opportunities for partnership working, evidence of tensions between organisations persist because of the competition for resources and authority. For example, we detected indications of resentment towards newer charities such as $\mathrm{H} 4 \mathrm{H}$, launched in 2007 . It's message of support and campaigns for those injured across the tri-services caught the public's imagination, resulting in over $f 131 \mathrm{~m}$ in unrestricted funds from voluntary income (2008-2012) $(\mathrm{H} 4 \mathrm{H}$, 2014a). However, it is clear from the $\mathrm{H} 4 \mathrm{H}$ website that they have been criticised for detracting publicity and funding from established Service charities:

The publicity generated by $\mathrm{H} 4 \mathrm{H}$ has meant that all Service charities have benefited considerably from the focus on this generation's wounded... Since H4H started, other Service charities have seen their income increase by more than 25\%... Media interest in $\mathrm{H} 4 \mathrm{H}$ has attracted attention to the important role that Servicemen and women play $(\mathrm{H} 4 \mathrm{H}, 2014 \mathrm{~b})$.

Despite these claims, the politicised terrain of post-transition welfare means that $\mathrm{H} 4 \mathrm{H}$ 's focus on personnel who have fought in conflicts since 2001 is controversial:

'The difference being that $\mathrm{H} 4 \mathrm{H}, \mathrm{I}$ 'm not being patronising here, but they only do it for people who have served since 2001. So, if you were a Falklands vet and you needed help, don't go to 
$H 4 H$, they can't help you. Or if you are a Northern Ireland vet, you know. So, that's the difference. Just a small point really, but significant' (Organisation 8, Interview, 19/06/12)

'I mean, I'm a little bit jealous about $\mathrm{H} 4 \mathrm{H}$ and all that ... We never had that kind of support, and yet we did the Gulf, Ireland, Bosnia, and Belize. I mean, Belize, to me, was horrendous because we were out back in the '80s. No one talks about that ... So, it's very good in a sense that it's now recognised. To me, it's like a bit too late...' (Veteran M, Interview, 14/09/12)

This further highlights the complexity of this sector with multiple charities and organisations working across the multiple needs of the tri-services, while some focus on a single issue, others are broader in scope connecting to a particular regiment, service or time frame, while others take a holistic approach:

'...you've got a whole raft of private, charitable, and state interventions against the whole raft of different requirements, whether required at early service team or the wounded, the injured, and the sick, the medically discharged, the ministry discharged, the person who's done 40 years ago, who's done 10 years, they're all different, and the family requirements are different too' (Organisation 2, Interview, 25/06/12)

Attempts have been made through COBSEO to clarify this environment and it has attempted to group charities into clusters in a bid to improve information sharing and partnership working. Despite these efforts towards harmonisation, the military welfare landscape remains a confusing terrain of multiple organisations and changing relationships. Through their delivery of welfare provision, military charities support ex-Service personnel in their experiences of moving both ways along the military-civilian continuum but, ultimately, their position as boundary subjects shapes these interactions. Dependent on the continuation of the boundary to justify their role in this ever more complex, overlapping and competitive welfare landscape, this impacts on how care is experienced and accessed by the end-user, arguably perpetuating this multiplicity as organisations continue to strive to maintain their positions and relative power. Furthermore, in their rhetoric and practices, organisations both implicitly and explicitly reinforce the perception of the binary on which 
they depend, which may not always be helpful or useful for an individual's welfare requirements. Finally, the proliferation of the third sector and its hybridisation, consequent of the changing role of the state, uncertain funding and changing political environments (Smith, 2010), means that while military welfare remains grounded in relations of care, it is also increasingly entangled in broader networks of market forces and inter-agency politics.

\section{Conclusions}

While we agree with Woodward (2004) that the military-civilian divide is blurred and porous, we argue that it remains important to understand and analyse this boundary because of its continuing discursive and practical performance by the third sector, state and ex-Service personnel; it clearly remains an important factor in shaping identities and relations (Herman and Yarwood, 2014). In this paper we focus on two of the multiple ways in which people engage with this boundary - bridging and crossing - to analyse the confused patterned-ground and complex inter-agency politics that characterise and govern Service-focused welfare in the UK. The rollback of the welfare state has allowed for the increasing role of the third sector in this arena and, in this paper, we provided insights into the complex nature of the latter's relations with this border zone between military and civilian as well as between the state, market and community. We noted that, while military charities have a caring role in supporting individuals making the transition to 'Civvy Street', their relevance and role remains fundamentally dependent on the continuing perception of a divide. They therefore have an interest in perpetuating and servicing perceived differences between military and civilian spaces, cultures and needs as well as emphasizing their liminal status, which they position as enhancing their welfare authority and capacity in contrast to the state and market. We conceptualise these organisations as 'boundary subjects', building on previous theorisations of boundaries to include more active agency, tactical positioning and the contingency of a more relational understanding of border-zones. This offers a more contextually grounded conceptual 
framing of the role of the third sector in military welfare, which is useful as it connects this into the broader economies and politics in which this also increasingly operates.

Recognising the role of boundary subjects in perpetuating the military-civilian binary discourse has important implications for shaping the geographies and social orderings of military welfare. Here, relations of care become recognised as embedded in the broader politics and market forces inherent in agencies jostling for authority and survival. In turn, this shapes the delivery of welfare and how it is experienced arguably establishing more changeable and contingent environments of care for individuals to negotiate. This highlights the dynamism and complexity of the relations between individual ex-Service personnel and military charities, with the former not just as 'service users' but as active agents in what and how they use, as well as how the charities themselves are framed. To us, this suggests that even though a 'binary' persists in the language and actions of military charities, the self-understandings and performances of all the actors in this 'post-Service landscape' is better understood as a continuum. This operates both ways, at multiple scales and is fluid and contextual; an organisation may position itself simultaneously closer to one end to connect to a particular regiment and to the other to draw on support. An individual may change how they identify during the course of a conversation and, even after many years as a 'civilian', can still draw on military experiences.

One consequence of this boundary subject status for organisations is a co-option into neoliberal welfare strategies. Although charities and other NGOs may critique the rollback of the state and increasing emphasis on individual responsibility, the needs that this has left unaddressed provides a justification for their existence, which they are unlikely to criticise. The proliferation of military charities in recent years combined with the continuing, if limited, role of state agencies leaves the delivery of welfare services a competitive arena in which the politics of survival jostle with the responsibility to do the best for the service user. Popular perceptions of the latter - those in need of welfare support - have changed over time with circumstances and legislation but arguably the Victorian-era separation of the 'deserving' and 'undeserving' poor persists. Although the social 
covenant made between military personnel and the state arguably ends when the former leave the Services, it continues to shape public attitudes towards ex-Service individuals. This is mobilised by military charities through the discourse of the 'heroic poor', a depoliticised but deserving individual; despite this, the fact that ex-Service personnel form 6\% of London's homeless (Johnsen et al., 2008) and 9.1\% of English and Welsh prisoners (MacManus and Wessely, 2011) indicates that the promises of in and post-Service welfare are not always being met. A clearer and more navigable welfare system is essential to support ex-Service personnel who are 'going from a small close-knit community to just being... just a normal person' (Veteran C, interview, 10/12/12). 


\section{References}

Alcock P, 2012, "New Policy Spaces: the impact of devolution on third sector policy in the UK" Social Policy \& Administration 46 219-238

Ancona D G, Caldwell D F, 1992, "Bridging the Boundary: external activity and performance in organizational teams" Administrative Science Quarterly 37 634-665

Ashcroft M, 2014, "The Veterans' Transition Review", http://www.veteranstransition.co.uk

Basham V M, 2013 War, Identity and the Liberal State: everyday experiences of the geopolitical in the armed forces (Routledge, Abingdon)

Bode I, Brandsen T, 2014, "State-Third Sector Partnerships: a short overview of key issues in the debate" Public Management Review 16 1055-1066

Brandsen T, Pestoff V, 2006, "Co-Production, the Third Sector and the Delivery of Public Services" Public Management Review 8 493-501

Carlson B E, Stromwall L K, Lietz C A, 2013, "Mental Health Issues in Recently Returning Women Veterans: Implications for Practice" Social Work 58 105-114

Chaney P, Wincott D, 2014, "Envisioning the Third Sector's Welfare Role: critical discourse analysis of 'post-devolution' public policy in the UK 1998-2012" Social Policy \& Administration 48 757-781

Charity Commission, 2012, "Support for armed forces Veterans: Briefing for Welsh Affairs Select Committee - Charity Commission",

Cowen D, 2005, "Welfare warriors: towards a genealogy of the soldier citizen in Canada" Antipode 37 654-678

Cowen D, 2008a Military workfare: the soldier and social citizenship in Canada (University of Toronto Press, Toronto)

Cowen D, 2008b, "The Soldier-Citizen", in Recasting the Social in Citizenship Ed E Isin (University of Toronto Press, Toronto) pp 189-209

Cowen D, Siciliano A, 2011, "Surplus Masculinities and Security" Antipode 43 1516-1541

Dandecker C, Wessely S, Iverson A, Ross J, 2006, "What's in a Name? Defining and Caring for 'Veterans': the United Kingdom in an international perspective" Armed Forces \& Society 32 161-177 
Defourny J, Nyssens M, 2010, "Social Enterprise in Europe: at the crossroads of market, public policies and the third sector" Policy and Society 29 231-242

DeVerteuil G, Wilson K, 2010, "Reconciling Indigenous Need with the Urban Welfare State? Evidence of Culturally-Appropriate Services and Spaces for Aboriginals in Winnipeg, Canada" Geoforum 41 498-507

Devon County Council, 2014, "South West Penisula (Devon, Plymouth, Torbay, Cornwall and Isles of Scilly) Veterans' Health Assessment Needs", (Devon County Council, Exeter)

Edwards R, Fowler Z, 2007, "Unsettling Boundaries in Making a Space for Research" British Educational Research Journal 33 107-123

Finlayson G, 1994 Citizen, State and Social Welfare in Britain, 1830-1990 (Clarendon Press, Oxford)

Fossey M, 2013, "Transition Support for British Army Early Service Leavers: An evaluation of the Future Horizons Programme", (RFEA, ITC Catterick London:)

Gal U, Yoo Y, Boland R J, 2004, "The Dynamics of Boundary Objects, Social Infrastructures and Social Identities" Working Papers on Information Systems 4 194-206

Gieryn T, 1999 Cultural Boundaries of Science (The University of Chicago Press, London)

H4H, 2014a, "Annual Reports", www.helpforheroes.org.uk/how-we-help/about-us/annualreports/

H4H, 2014b, "FAQs", www.helpforheroes.org.uk/how-we-help/about-us/faqs

Herman A, Yarwood R, 2014, "From Service to Civilian: the geographies of post-military lives" Geoforum 53 41-50

Higate P, 2000, "Ex-servicemen on the road: travel and homelessness" Sociological Review 48 331-348

Johnsen S, Jones A, Rugg J, 2008 The experiences of homeless Ex-service personnel in London (Centre for Housing Policy, York)

Karsten $\mathrm{H}$, Lyytinen K, Hurskainen M, Koskelainen T, 2001, "Crossing Boundaries and Conscripting Participation: representing and integrating knowledge in a paper machinary project" European Journal of Information Systems 10 89-98

Kearns R A, Joseph A E, 1997, "Restructuring Health and Rural Communities in New Zealand" Progress in Human Geography 21 18-32 
Kendall J, 2009, "The Third Sector and the Policy Process in the UK: ingredients in a hyperactive horizontal policy environment", in Handbook of Third Sector Policy in Europe: multi-level processes and organised civil society Ed J Kendall (Edward Elgar, Cheltenham)

Law J, Singleton V, 2005, "Object Lessons" Organization 12 331-355

MacLeavy J, Peoples C, 2009, "Workfare-Warfare: Neoliberalism, "Active" Welfare and the New American Way of War " Antipode $\mathbf{4 1}$

MacManus D, Wessely S, 2011, "Why do some Ex-Armed Forces Personnel end up in Prison?" British Medical Journal 343 4-5

Mechanic M B, 2004, "Beyond PTSD: Mental health consequences of violence against women - A response to Briere and Jordan" Journal of Interpersonal Violence 19 1283-1289

Milbourne L, 2009, "Remodelling the Third Sector: advancing collaboration or competition in community-based initiatives?" Journal of Social Policy 38 277-297

Milligan C, Fyfe N R, 2005, "Preserving Space for Volunteers: exploring the links between voluntary welfare organisations, volunteering and citizenship" Urban Studies 42 417-433

Mohan G, Mohan J, 2002, "Placing Social Capital" Progress in Human Geography 26 191-210

Mohan J, 2003, "Voluntarism, Municipalism and Welfare: the geography of hospital utilization in England in 1938" Transactions of the Institute of British Geographers 28 56-74

Mumford A, 2012, "Veteran care in the United Kingdom and the sustainability of the 'Military Covenant' " The Political Quarterly 83 820-826

Najam A, 2000, "The Four-C's of Third Sector-Government Relations: cooperation, confrontation, complementarity, and co-optation" NonProfit Management \& Leadership 10 375-396

O'Leary P, Tsui M-S, Ruch G, 2013, "The Boundaries of the Social Work Relationship Revisited: towards a connected, inclusive and dynamic conceptualisation" British Journal of Social Work 43 135-153

Peck J, Tickell A, 2002, "Neoliberalizing Space" Antipode 34 380-404

Phillips S, Hebb T, 2010, "Financing the Third Sector: introduction" Policy and Society 29 181187

Pozo A, Walker C, 2014, "UK Arned Forces Charities: an overview and analysis", (Directory of Social Change, London) 
Riesch H, 2010, "Theorizing Boundary Work as Representation and Identity" Journal for the Theory of Social Behaviour $\mathbf{4 0} \mathbf{4 5 2 - 4 7 3}$

Skocpol T, 1992 Protecting Soldiers and Mothers: the political origins of social policy in the United States (Harvard University Press, Boston)

Smith S R, 2010, "Hybridization and Nonprofit Organizations: the governance challenge" Policy and Society 29 219-229

Valentine G, 2001 Social Geographies: space \& society (Pearson Education, Harlow)

Walker D I, 2013, "Anticipating Army Exit: Identity Constructions of Final Year UK Career Soldiers" Armed Forces \& Society 39 284-304

Ware V, 2010, "Whiteness in the glare of war: soldiers, migrants and citizenship. " Ethnicities $10313-330$

Watson-Manheim M B, Chudoba K M, Crowston K, 2012, "Perceived Discontinuities and Constructed Continuities in Virtual Work" Information Systems Journal 22 29-52

White M D, Mulvey P, Fox A M, Choate D, 2012, "A Hero's Welcome? Exploring the Prevalence and Problems of Military Veterans in the Arrestee Population" Justice Quarterly $29258-286$

Wolch J, 1990 The Shadow State: Government and Voluntary Sector in Transition (Foundation Center, New York)

Woodward R, 2004 Military geographies (Blackwell Pub., Malden, MA)

Yarwood R, 2011, "Voluntary sector geographies, intraorganisational difference, and the professionalisation of volunteering: a study of land search and rescue organisations in New Zealand" Environment and Planning C 29 457-472

\footnotetext{
' For example, 9150 personnel were reduced from the regular UK Armed Services in 2013 Berman, G. and T. Rutherford (2013). Defence Personnel Statistics. London, House of Commons Library. as the Ministry of Defence (MoD) works to address a $f 38 \mathrm{bn}$ funding gap National Audit Office (2012). Managing Change in the Defence Workforce, MoD.

ii Sampled from COBSEO's database of military charities.

iii To preserve the anonymity of our interviewees we refer to them as Veteran A, B etc. and Organisation 1, 2 etc.

iv Perhaps tellingly, there are no official data that precisely record the number of veterans in the UK.as the Census does not include a question on this issue. The data for Plymouth are based on estimates derived by the RBL and the Office of National Statistics.

${ }^{v}$ The number of registered armed forces charities actually fell by $7 \%$ between $2009-2012$ (Charity Commission 2012). These reflected the disbandment of World War Two regimental associations as their active membership fell away and the merger of others. In 2012, the
} 
income of many military charities started to decline (Pozo and Walker 2014) as operations in Afghanistan were scaled back and then ended in 2014.

vi These include those with a focus on veterans, social needs, skills and training, employment, financial support and advice, support for the families of Service personnel, disability support and rehabilitation, counselling and medical care, care homes, accommodation and benevolence.

vii In its launch speech Help for Heroes founder Bryn Parry stated 'It's about the 'blokes', the men and women of the Armed Forces' (Help for Heroes 2014)

viii This report provides comprehensive detail on the welfare services available to those leaving the forces and the difficulties some face in accessing them.

ix Our focus on 'successful' transition addressed a research gap because existing studies on military-civilian transition have predominantly focused on those with mental/physical illnesses; see, for example, Higate (2001) and Johnsen et al (2008). 